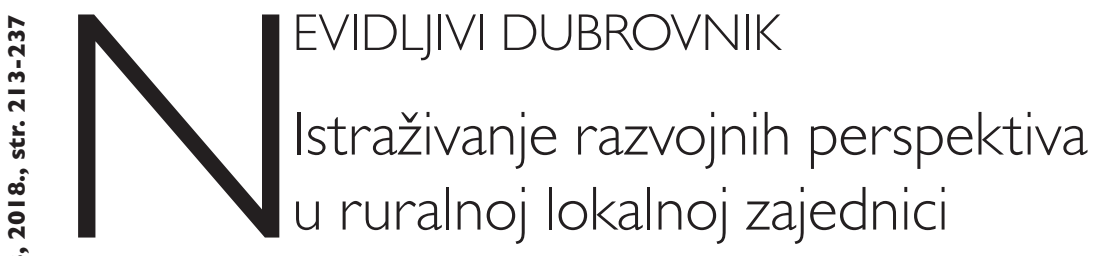

\author{
Nataša Bokan \\ Zavod za agrarnu ekonomiku i ruralni razvoj, \\ Agronomski fakultet, Sveučilište u Zagrebu

\section{Orlanda Obad} \\ Institut za etnologiju i folkloristiku, Zagreb
}

\begin{abstract}
Rad se bavi razvojnim perspektivama ruralnog područja Grada Dubrovnika. Cilj je istražiti izazove s kojima se poljoprivrednici susreću u radu i svakodnevnom životu, utvrditi potencijale za razvoj te ponuditi razvojne smjerove ruralne lokalne zajednice u Gradu Dubrovniku. Empirijsko je istraživanje provedeno metodom ankete i polustrukturiranog intervjua među pedeset tri poljoprivrednika/ce u svibnju 2016. godine u selima i drugim naseljima u ruralnom prostoru koja pripadaju Dubrovniku. Utvrđena su tri komplementarna razvojna smjera: diversifikacija ruralnih djelatnosti koja je povezana s konkuriranjem za fondove Europske unije, osnivanje zadruga i razvoj zadružnog načina suradnje te prelazak na ekološku poljoprivrednu proizvodnju. $U$ analizi se kritički sagledavaju razvojne prepreke u svim trima aspektima razvoja te se predlaže kako bi se razvojni potencijali mogli upotrijebiti na dobrobit lokalne zajednice. Slijedeći logiku neoendogenog ruralnog razvoja, autorice u zaključku ocrtavaju konture razvoja ruralnog područja Grada Dubrovnika koji bi, u socioekonomskom pogledu, u većoj mjeri integrirao Grad, ali ističu i prepreke na putu takvog razvojnog smjera u lokalnom kontekstu.

Ključne riječi: ruralni razvoj, diversifikacija, zadrugarstvo, ekološka poljoprivreda, Dubrovnik
\end{abstract}

Uvod' $^{\prime}$

Ako postoji neka strategija preživljavanja lokalnog stanovništva u ljetnim mjesecima u Dubrovniku, gradu koji godišnje bilježi više od milijun turističkih dolazaka, ${ }^{2}$ ona je proizvod prešutnog dvostrukog koda, koji je odraz nevidljive solidarnosti lokalnih

${ }^{1}$ Istraživanje je 2016. provela neformalna istraživačka skupina Ruralije, u sklopu projekta Dubrovačke razvojne agencije (DURA) pod nazivom "Agrobiznis - oplemenjivanje poljoprivredne baštine u prekograničnoj Dubrovačko-hercegovačkoj regiji”. Obje su autorice rada članice Ruralija. Ovaj je rad sufinancirala Hrvatska zaklada za znanost projektom “Transformacija rada u posttranzicijskoj Hrvatskoj” (IP-2016-06-7388).

${ }^{2}$ Prema Popisu stanovništva, kućanstava i stanova Državnog zavoda za statistiku (DZS) iz 2011., Grad Dubrovnik imao je više od 40 tisuća stanovnika, a područje je sastavljeno od 32 naselja, među kojima sâm Dubrovnik ima oko 28 tisuća stanovnika (DZS 2011). Prema podacima DZS-a o broju turističkih dolazaka i noćenja u 2017. godini, Grad Dubrovnik zabilježio je 1,17 milijuna dolazaka i 3,88 milijuna noćenja, što ga čini gradom s najviše turističkih noćenja u Hrvatskoj (DZS 2018). 
ugostitelja sa svojim sugrađanima. Ponekad, ovisno o kompleksnim i ne nužno dosljednim vrijednosnim sustavima, solidarnost se rasprostire i šire, na su-državljane, pa i na pripadnike entiteta koji danas neutralno zovemo regijom.

Da masovnost turizma, osobito u poodmaklim fazama razvoja, kod lokalnog stanovništva izaziva otpore nije nikakva novost. Na prikazima jednog od najatraktivnijih kupališta podno dubrovačkih zidina, Buže, fotografi rijetko zahvaćaju veliki crveni grafit "PRIVATE AREA", kojim si lokalni kupači pokušavaju rezervirati prostor za neometano sunčanje. Kao nelokalac, nekada ćete se zateći kako uzaludno protestirate što vas je pretekao neki gospar, odjeven u kratko odrezane traperice i bijelu potkošulju, na Konzumovoj blagajni. Hrvatskih gostiju nema mnogo, pa si gospar i gospođa na blagajni, i sama ne nužno Dubrovkinja, mogu priuštiti da i naglas prokomentiraju nesnosne gužve u gradu, buku u apartmanu, koja ih je sinoć do ranih jutarnjih sati držala budnima, ili novu odredbu prema kojoj je neka od cijena usluga za lokalno stanovništvo poskupjela.

Ako ste lokalno dobro umreženi, ako vas prime "pod svoje", u Dubrovniku ćete "unutar zidina" preživjeti i u ljetnim mjesecima. Začudo, ali još postoje mjesta na kojima kava košta devet kuna, stalnim mušterijama mnogi ugostiteljski objekti odobravaju popust; za lokalne trgovine upozoravaju da su znatno skuplje nego okolni trgovački centri, a tu je i pjaca, na kojoj možete kušati i lokalno voće i povrće. To je, ujedno, jedno od rijetkih mjesta u središtu grada na kojem se možete susresti s manje vidljivim, ruralnim dijelom Grada Dubrovnika. I to samo ako među prodavačima uspijete pronaći nekoga tko dolazi baš iz dubrovačkih sela - a takvih nije mnogo - između ostalog i zato što osviještenosti o potrebi za solidarnosti koja postoji na "potrošačkom" kraju lanca nema na njegovu početku, ondje gdje se hrana proizvodi. Na selu.

U ovome ćemo se radu posvetiti upravo dijelovima Grada koji su ruralni i koji sadrže naselja u kojima turizam još nije zaživio ili, pak, nije glavni izvor prihoda lokalnog stanovništva. Epistemološki, ovaj rad kroči u hrvatskom kontekstu nedovoljno istraženim teritorijem angažirane znanosti. Već detektirane stranputice društvenih znanosti i humanistike (usp. Bagarić, Biti i Škokić 2017), uključuju i projektificirani pristup znanstvenoj spoznaji, koji je prisutan i u ovome radu. Pojedini autori u skretanju humanistike u projektifikacijske sfere uviđaju i priliku za snažniji angažman znanstvenika u zajednici, na tragu pristupa nekih od klasika u istraživanju hrvatskog rurala kakav je rad Rudolfa Bićanića (usp. Orlić, Bagarić i Obad 2016). Ovaj članak, između ostalog, propitkuje je li moguće znanstvene spoznaje upregnuti u potrebe lokalne zajednice, onkraj uobičajene razdjelnice između "stručnog" i "znanstvenog" pristupa. Umjesto da na stolac za ispitivanje posjednemo uobičajenog osumnjičenika, pitamo se nije li upravo angažirani pristup znanosti odgovarajuća reakcija na, u mnogočemu dramatično, stanje na hrvatskom selu. Ovaj rad posvećujemo, između ostalog, namjeri da glasovi odozdo ne (p)ostanu bespomoćni.

Članak predstavlja rezultate opsežnog kvantitativnog i kvalitativnog istraživanja, čiji je cilj bio ustanoviti potencijale i potrebe za razvojem ruralnog dijela Dubrovnika. Za potrebe rada izdvojile smo tri aspekta koja smo, u srazu istraživačkih pitanja koja odražavaju suvremene paradigme ruralnog razvoja s lokalnim razvojnim perspektivama, prepoznale kao ključne za razvoj ruralnog područja Grada Dubrovnika 
- diversifikaciju ruralnih djelatnosti; osnivanje zadruga i promoviranje zadružnog poslovanja; te prelazak na ekološku poljoprivrednu proizvodnju. U analizi smo kritički sagledale razvojne prepreke u svim trima aspektima i predložile strategije uz pomoć kojih bi razvojni potencijali mogli poslužiti lokalnoj zajednici. U zaključku, pak, izdvajamo i projektne zamisli koje bi, socioekonomski, vodile boljem integriranju sada odvojenih cjelina Grada. U zamišljanju prijedloga vodile smo se logikom neoendogenog (ruralnog) razvoja koja uvažava princip odozdo prema gore, ali i dovele u pitanje neke njegove aspekte.

\section{Teorijska perspektiva}

Danas se Dubrovnik u društvenim znanostima najčešće istražuje iz perspektive turizma, pri čemu autori navode negativne posljedice muzealizacije stare jezgre, zanemarivanje "periferije”, tj. svega izvan zidina (Kunst 2017) i štetnosti masovnog i neplaniranog turizma (Šulc u tisku; Šulc 2017; Ban i Vrtiprah 2003). Također se navodi kako je turizam u Dubrovniku dosegnuo fazu stagnacije oko 2005. - 2010. da bi potom ponovno počeo rasti (Šulc 2017; Šulc u tisku), premašujući posljednjih nekoliko godina milijun dolazaka godišnje. Istodobno, autori govore o potrebi za uvođenjem "dubrovačke periferije u turističku ponudu” kako bi "turistički doživljaj bio potpuniji i kvalitetniji" (Kunst 2017: 70), a lokalno stanovništvo zadovoljnije; o potrebi za korištenjem bogatog kulturnog nasljeđa u turizmu (Ban i Vrtiprah 2003), kao i o potrebi za ekoturizmom kao strategiji osiguravanja održivosti (Miljak, Bačić i Kitić 2012).

Izuzmemo li recentno istraživanje o broju i kapacitetu ruralno-turističkih gospodarstava u dalmatinskoj ruralnoj regiji (uključujući Dubrovnik) (Svržnjak et al. 2017), u kojem je utvrđeno da u dubrovačkoj regiji postoji relativno velik broj seljačkih domaćinstava, izostaju istraživanja ruralnog dijela Grada Dubrovnika, a posebice ona koja bi obuhvatila i perspektivu njegova lokalnog stanovništva. Prostor za istraživanje pronašle smo upravo u pitanjima koja sežu onkraj turizma, primjerice: koji je položaj dubrovačkog rurala spram urbanog Dubrovnika, koji problemi artikuliraju simboličke granice urbanog i ruralnog dijela Grada, postoje li i koji su potencijali ruralnoga "zaleđa" i otoka, teže li njihovi stanovnici poljoprivredi ili turizmu, odnosno kako razvoj tih djelatnosti zamišljaju. Namjera nam je bila umanjiti prazninu u suvremenim istraživanjima hrvatskog rurala istraživanjem koje iz perspektive poljoprivrednika sagledava potencijale za neoendogeni razvoj gotovo nevidljivog, ruralnog Dubrovnika.

Tri najavljene teme ovog rada dio su jedinstvene konceptualne platforme - neoendogenog ruralnog razvoja ${ }^{3}$ - na koju se teorijski oslanjamo. Ona se zasniva na pri-

\footnotetext{
${ }^{3}$ (Neo)endogenom ruralnom razvoju prethodi koncept integralnog ruralnog razvoja (IRR), nastao 1960-ih i 1970-ih u zemljama u razvoju, a uveden u Europi 1980-ih kao opozicija sektorskoj ruralnoj politici. IRR je predstavljao u osnovi teritorijalni pristup pri čemu se naglašavalo koordiniranje različitih državnih sektora na lokalnoj razini (Shucksmith 2010). Počevši od 1990-ih, LEADER (Liaison Entre Actions de Développement de l'Économie Rurale, skup načela koji je razvila EU kako bi podržala projekte ruralnog razvoja što ruralna područja sagledavaju
} 
stupu odozdo, i zagovara poticanje razvoja kroz participativnost, odnosno korištenje lokalnih resursa i mehanizama, i ekstralokalnost, koja označava nužnost oslanjanja na političko-administrativne aktere na svim razinama, kao i na one iz drugih lokaliteta (Ray 2006). Neoendogenim se pristupom razvoju kroz zajedničko djelovanje lokalnih i ekstralokalnih dionika pokušava postići bolja kvaliteta života.

Neoendogeni se pristup zasniva na ideji da se socioekonomska dobrobit (trenutno deprivilegirane ruralne ekonomije) najbolje postiže restrukturiranjem javnih intervencija, uz davanje prednosti ne više individualnim sektorima već mozaiku lokalnih/regionalnih zajednica. (Ray 2006: 278)

Takav pristup podrazumijeva da se problemi (ruralne) "periferije” više ne rješavaju u (urbanom) "centru" i sektorski, i to upravo stoga što se pretpostavlja da su problemi obilježeni lokalitetom i kulturom pojedine zajednice. U skladu sa središnjom potkom neoendogenog pristupa, nužno je da područje stekne kapacitet za preuzimanje odgovornosti za vlastiti socioekonomski razvoj. To se, među ostalim, postiže sudjelovanjem lokalnog stanovništva u planiranju i provedbi teritorijalnog razvoja, između ostalog, i doprinosom kroz vlastite resurse.

Prema Rayu (2006), neoendogeni je ruralni razvoj sklop ideja koji se oslanja na nekoliko međusobno povezanih pristupa. Jedan je od njih socijalna ekonomija, koja nalaže da se suvremene ekonomije razumijeva unutar društvenog konteksta u kojem se odvijaju, pa su u njihovu proučavanju neizostavna pitanja suradnje, demokratičnosti i smislenog rada (Sayer i Walker 1992). Jedan je od važnih aktera socijalne ekonomije i civilno društvo koje, između ostalog, podrazumijeva neprofitno djelovanje temeljeno na načelima solidarnosti, suradnje i društveno angažiranih ciljeva. Drugi je važan pristup ekonomska usklađenost, koja Polanyijevu ekonomsku integraciju kroz uzajamnost, preraspodjelu i tržišnu razmjenu, a nasuprot obrascima socijalne organizacije kao što su dualnost, centrizam ili atomistički individualizam, čini sastavnim dijelom promišljanja i teoretiziranja, ali i donošenja politika. Napokon, treći pristup koji oblikuje neoendogeni ruralni razvoj višerazinsko je upravljanje i teritorijalnost. To ne pretpostavlja da se pojedino područje razvija sâmo, odvojeno od šire ekonomsko-političke zajednice, već da endogene inicijative u traženju novčane i druge vrste podrške prije ili kasnije posežu za ekstralokalnim razinama, od one nacionalne pa sve do razine Europske unije (Ray 2006).

U raspravi o suvremenim pristupima ruralnom razvoju nezaobilazan je koncept i multifunkcionalnost poljoprivrede. I dok postoji konsenzus o tome da je multifunkcionalnost važna, o tome što ona znači i kako valja izgledati u primjeni suglasja

u perspektivi široj od one poljoprivredne) predstavlja srodan model ruralnog razvoja koji promovira endogeni pristup, gradeći kapacitet lokalnog ruralnog stanovništva da se odupire širim globalnim natjecanjima, krizama i socijalnoj isključenosti. Budući da LEADER zauzima (financijski) razmjerno mali dio mjera Zajedničke poljoprivredne politike, čini se da ima izraženiju simboličku nego materijalnu snagu (Shucksmith 2010). K tome je i OECD prije desetak godina utvrdio da, unatoč provođenju IRR-a, u mnogim državama Europske unije nedostaje integrirane ruralne politike, ili je ona, pak, visoko centralizirana, s nedovoljnim stupnjem osnaženosti lokalnih zajednica (OECD 2008 prema Shucksmith 2010), pa se počinje predlagati (neo)endogeni pristup ruralnom razvoju koji bi teritorijalne zajednice poticao da se prema vlastitom razvojnom smjeru mobiliziraju u partnerstvu s drugim akterima - zajednicama, institucijama, vladama... 
nema. Marsden i Sonnino (2008) tvrde da se različiti razvojni diskursi otimaju za ovaj pojam tumačeći ga, pritom, na različite načine. U agroindustrijskoj paradigmi, koja preferira logiku razmjera, specijalizaciju i monokulturnu proizvodnju, multifunkcionalna je poljoprivreda svedena na pojam pluriaktivnosti, odnosno puku strategiju preživljavanja za one poljoprivrednike koji ne uspijevaju zadovoljiti tržišne uvjete. U postproduktivističkoj paradigmi, koja ruralna područja percipira kao mjesta potrošnje, suprotstavljajući se pritom agroindustrijskoj paradigmi naglašavanjem važnosti planiranja i očuvanja okoliša (riječ je, primjerice, o očuvanju krajobraza koji se na tržištu želi ponuditi kao potrošačko dobro), multifunkcionalna se poljoprivreda tumači kao diversifikacija poljoprivrednog zemljišta.

U trećoj, paradigmi održivog ruralnog razvoja, koja je bliska perspektivi ovoga rada, naglašava se sociookolišna uloga poljoprivrede kao temeljnog čimbenika u održanju ruralnih ekonomija i kultura. Za razliku od prvih dviju paradigmi, ovaj pristup naglašava da odnos poljoprivrednih farmi i njihovih lokalnih zajednica može biti simbiotski. Iz te se perspektive multifunkcionalnost smatra "proaktivnim razvojnim alatom za promoviranje održivije ekonomije obuhvata i sinergije", čije aktivnosti trebaju "stvarati mogućnosti za dodatni dohodak i zaposlenje u poljoprivredi, doprinositi stvaranju novog poljoprivrednog sektora koji odgovara potrebama i očekivanjima šireg društva te radikalno redefinirati i preoblikovati ruralne resurse, na i onkraj poljoprivrednog gospodarstva" (Marsden 2003: 185-186 prema Marsden i Sonnino 2008: 423).

Upravo u dvama potonjim tumačenjima multifunkcionalnosti vidimo mogućnosti koje bi mogle primijeniti istražene lokalne zajednice.

Uloga se lokalnih dionika također različito poima u pojedinim pristupima ruralnom razvoju, a prijelaz s jednog pristupa na drugi lakše je provediv u teorijskom diskursu, nego "na terenu". Sektorski pristup, primjerice, u razvojnim aktivnostima obuhvaća manje dionika i aktera, a njihove su djelatnosti manje raznolike što uvjetuje lakše oblikovanje intervencija ruralnih politika. S druge strane, u teritorijalnom je pristupu teže ustanoviti politike i upravljati njihovom provedbom i taj pristup iziskuje obuhvatniju i inkluzivniju vrstu stručnosti u osmišljavanju i provođenju ruralne politike (Dax i Copus 2016). Potonje potvrđuju i autori koji se kritički postavljaju spram teritorijalnog pristupa, koji upozoravaju kako on nije zalog postizanja jedinstvenog interesa određene lokalne zajednice koja obuhvaća niz heterogenih aktera s različitim, a ponekad i suprotstavljenim interesima (Shucksmith 2010). To je upravo jedan od razloga zašto u ovome radu inzistiramo na ruralnosti kao određujućem faktoru značajnog dijela Grada Dubrovnika, premda smo svjesne da se tradicionalnom djelatnošću ljudi u ruralnom prostoru - poljoprivredom - na tom području danas bavi manji dio stanovništva. ${ }^{4}$ Naime, prepoznavanje navedenih prostora kao ruralnih olak-

\footnotetext{
${ }^{4}$ Prema podacima iz ARKOD-a, nacionalnog sustava evidencije zemljišnih parcela, iz 2017., površina poljoprivrednog zemljišta na kojoj je registrirana poljoprivredna proizvodnja na području Grada Dubrovnika je oko 330 hektara (najviše pod maslinicima), što je površina koju u Slavoniji imaju pojedine (velike) farme (ARKOD 2017). S druge strane, na području naselja Orašac 2016., kada smo provodili istraživanje, boravilo je više od 50 tisuća turista - najviše u hotelskom smještaju, a na području svih tridesetak naselja Grada, izuzme li se Dubrovnik, bilo je više od 100 tisuća gostiju (DZS 2017). Službena će statistika sva ta područja svrstati pod "ruralna i prijelazna naselja",
} 
šava nam da u dubrovačkom kontekstu progovorimo o održivom razvoju i o načelima kakva, primjerice, zagovaraju principi "lokalnog razvoja pod vodstvom zajednice" (community-led local development), koji su izrasli iz LEADER-a, i koji se mogu primijeniti i u urbanim sredinama. Jednako tako, progovaranje iz ne-turističke perspektive, kao što je ona poljoprivredna, u kontekstu Dubrovnika nosi potencijal diskurzivnog zahvata u prostor kojim trenutačno vlada status quo. U skladu s onime na što upozorava Shucksmith (2010), ni interesi za razvoj turistificiranih dionika lokalnog razvoja, recimo, vlasnika hotela ili iznajmljivača apartmana, ne moraju biti homogeni, niti jednaki interesima lokalnih poljoprivrednika ili sezonskih radnika. Svjesne da ne prikazujemo "većinsku" perspektivu, u ovom radu želimo pokazati kako "manjinski" glasovi mogu doprinijeti iscjeljujućim promjenama perspektive i fokusa. ${ }^{5}$

\section{Metodologija}

Opća istraživačka pitanja kojima je započelo ovo istraživanje odnose se na specifičnosti dubrovačkog rurala. Zanimali su nas neki aspekti kvalitete života, odnos prema poljoprivrednoj djelatnosti, prema (potencijalnoj) turističkoj djelatnosti, odnosima na tržištu (poljoprivrednom, turističkom) i, općenitije, razvojna perspektiva koja proizlazi iz postojećih resursa u lokalnoj ruralnoj zajednici.

Uzorak u ovom istraživanju činili su poljoprivrednici/e, tj. nositelji/ce ili članovi/ice obiteljskog poljoprivrednog gospodarstva (OPG-a). Razlog odabira upravo poljoprivrednika/ca za sudionike/ce u našem istraživanju pronašli smo, osim u samim istraživačkim pitanjima, i u činjenici da su znanstvena istraživanja među poljoprivrednicima i poljoprivrednicama u Hrvatskoj sve rjeđa, a kvalitativna istraživanja na uzorku poljoprivrednika/ca gotovo da ne postoje. ${ }^{6}$

U empirijskom dijelu istraživanja koristili smo kvantitativnu i kvalitativnu metodologiju - metodu ankete i polustrukturiranog intervjua. Pitanja u anketi odnosila su se na tri područja: strukturu obitelji i socioekonomske aspekte kućanstva; strukturu poljoprivredne proizvodnje i socioekonomske aspekte OPG-a; socijalni kapital i kvalitetu života u mjestu te ideje za razvoj lokalne zajednice. Neke su teme za pro-

premda je jasno da između "grada" i "sela" stoji više od "prijelaza” i suburbije, jer nije (uvijek) riječ o urednom stupnjevanju dvaju polova. U konkretnom primjeru, stari ljetnikovci podsjećaju na stoljetna prožimanja, supostojanje urbanog i ruralnog, a usporedo s današnjim hotelima, svjedoče i o kontinuitetu želje za odmorom i dokolicom, te o diskontinuitetu društvenog uređenja i tehnološkom napretku koji za posljedicu imaju u bitnome promijenjenu dostupnost istih. Ruralnost, dakako, nije istovjetna s poljoprivredom, ali dugotrajna deagrarizacija pospješuje gubitak identiteta i opadanje broja stanovnika ruralnog područja, a ugrožena je i agrobioraznolikost, dok se priroda "vraća" s nizom, za ljude neželjenih, posljedica. Iz perspektive provedenog istraživanja, možemo ustvrditi da su, primjerice, tzv. Gornja sela danas "ruralnija” od većine dubrovačkih naselja, a čini nam se da se, u tom smislu, izdvaja i otok Šipan. Druga su (priobalna) naselja, poput spomenutog Orašca, pod većim utjecajem turistifikacije, dok naselja poput Nove Mokošice spadaju u prigradska naselja - bez ruralnog karaktera i potencijala koji ruralnost nosi - kojima se u ovom radu nismo bavile. Nekom budućem istraživanju prepuštamo da se detaljnije pozabavi urbano-ruralnom klasifikacijom dubrovačkih naselja.

${ }^{5}$ Dakako, predlažemo da se u narednim istraživanjima istraže i perspektive drugih dionika u toj lokalnoj zajednici i Gradu - od nepoljoprivrednog stanovništva, lokalnih udruga, žena, mladih, starijeg stanovništva, sve do razvojnih agencija, LAG-a i gradske vlasti.

${ }^{6}$ Iznimke su Obad 2012 i dijelom Bušljeta Tonković 2015. 
tokol intervjua bile pripremljene, a druge su proizašle iz rezultata anketiranja i one obuhvaćaju sljedeće tematske cjeline: motivaciju za poljoprivredu, stavove o ekološkoj proizvodnji, stanje na tržištu te spremnost za prijave na EU fondove. Razmjerno široke tematske cjeline $\mathrm{u}$ intervjuima urodile su nekolicinom tematskih okosnica $\mathrm{u}$ skladu s kojima smo u radu koncipirale kodne cjeline.

Prikupljanje podataka provedeno je u svibnju 2016. godine u dubrovačkim selima i drugim vrstama naselja u ruralnom području, ${ }^{7} \mathrm{u}$ tzv. Gornjim selima (Gromača (141/20), ${ }^{8}$ Kliševo (55/5), Mravinjac (80/3), Mrčevo (86/6), Osojnik (297/13)), tzv. Donjim selima (Komolac (313/16), Orašac (625/63), Trsteno (221/16), Zaton $(1001 / 24)$ ) te na Elafitima, otocima Koločepu, Lopudu i Šipanu (Lopud (249/7), Suđurađ (203/16), Šipanska Luka (211/35)). Proveli smo namjerno uzorkovanje $^{9}$ pri čemu smo s popisa OPG-ova (APPRRR 2016) izabirali sugovornike/ce prema kriteriju pripadnosti različitim geografskim cjelinama (otoci, unutrašnjost, priobalna naselja), ${ }^{10}$ pokušavajući, ujedno, obuhvatiti raznolikost lokalne poljoprivredne proizvodnje. ${ }^{11}$ Istraživanjem je obuhvaćeno 53 mještana/ke u 12 naselja u sklopu Grada Dubrovnika. ${ }^{12}$ Dvije trećine (68 posto) sugovornika/ca su nositelji/ce OPG-a, ostali su članovi/ice OPG-a. Tri četvrtine (74 posto) sugovornika/ca su muškarci, a jedna četvrtina (26 posto) - žene. Prevladavaju zrele i starije dobne skupine (Tablica 1). Obitelji su sugovornika/ca većinom nuklearne, a 40 posto je proširenih. U prosjeku imaju tri izvora prihoda u kućanstvu.

\begin{tabular}{|l|c|}
\hline Dob sugovornika/ca & F \\
\hline $21-30$ & 0 \\
\hline $31-40$ & 3 \\
\hline $41-50$ & 15 \\
\hline $51-60$ & 16 \\
\hline $61-70$ & 11 \\
\hline 71 i više & 8 \\
\hline Ukupno & 53 \\
\hline
\end{tabular}

Tablica I. Dob sugovornika/ca u istraživanju

\footnotetext{
${ }^{7}$ Zahvaljujemo sugovornicima i sugovornicama na vremenu i trudu uloženom u odgovaranje na pitanja.

${ }^{8}$ Prvi broj u zagradama označava broj stanovnika prema podacima iz Popisa 2011. godine - ukupno je u navedenim naseljima 3482 stanovnika (DZS 2011). Drugi, pak, broj označava broj obiteljskih poljoprivrednih gospodarstava u pojedinom naselju - ukupno ih je na području Grada Dubrovnika, krajem 2016., bilo prijavljeno 550 (APPRRR 2016).

${ }^{9}$ Pristup sugovornicima je koordiniran uz stručnu pomoć Razvojne agencije grada Dubrovnika DURA.

${ }^{10}$ Unutar triju geografskih cjelina sugovornike smo izabrale prigodnim uzorkovanjem, prema njihovoj raspoloživosti za razgovor.

${ }^{11}$ Od ukupnog broja sugovornika, njih se 91 posto bavi maslinarstvom, 76 posto povrćarstvom, 51 posto voćarstvom, 43 posto vinogradarstvom, 32 posto stočarstvom, 9 posto ratarstvom i 8 posto pčelarstvom.

${ }^{12}$ Anketiranje je i intervjuiranje proveo dio istraživačkog tima, osobno i većinom u domovima sugovornika/ca. $\mathrm{Na}$ intervju nisu pristali svi anketirani sugovornici/e pa je kvalitativnim dijelom istraživanja zahvaćeno 45 poljoprivrednika/ca. Svi su razgovori (anketiranje i intervjuiranje) snimani diktafonom uz dopuštenje sugovornika/ca i trajali su do sat i deset minuta. Intervjue su u cijelosti transkribirale dvije istraživačice, od kojih je jedna autorica ovog rada. Svi su transkripti šifrirani i ručno kodirani.
} 
Većina sugovornika/ca (41 odnosno 77 posto) ima srednju stručnu spremu, njih osam (15 posto) ima više ili visoko obrazovanje, a osnovno obrazovanje njih četiri ( 7 posto). Svega dvoje sugovornika/ca (4 posto) ima formalno poljoprivredno obrazovanje.

U ovom smo radu obradile dio prikupljenih podataka, jer opseg istraživanja nadilazi okvire znanstvenog članka. Oslonile smo se prvenstveno na rezultate intervjua, izuzev podataka o povjerenju i sociodemografskim obilježjima koji su rezultat anketiranja. Rezultati su obrađeni deskriptivnim i analitičkim kodiranjem, nakon čega su kodovi grupirani u šire kodne grupe, postavljene u analitički okvir koji je predstavljen u kodnoj shemi priloženoj na kraju rada. U narednim trima poglavljima obrađujemo tri socioekonomska aspekta razvoja koja smo najavile u uvodu. Kako bismo osigurale anonimnost sugovornika/ca, u navođenju citata označile smo samo naselje, bez uobičajenih osobnih obilježja (godine, spol, zanimanje).

\section{Diversifikacija - "Dubrovnik nisu samo zidine i Stradun, ovo je sve Republika."}

Ruralni razvoj podrazumijeva razvoj seoskog područja i mimo poljoprivredne proizvodnje, pri čemu je upravo diversifikacija, kao metoda usložnjavanja djelatnosti kojima se stanovnici ruralnih područja bave, jedna od mogućih strategija opstanka različitih oblika ruralnih zajednica, koje uključuju i pojedinačne OPG-ove. Diversifikacija se, primjerice, može odnositi na uvođenje raznolikosti poljoprivrednih djelatnosti pa se tako proizvodnja primarnih proizvoda može nadopuniti preradom proizvoda, ali se može odnositi i na širenje djelatnosti na samom obiteljskom gospodarstvu i u lokalnoj zajednici koje mogu i ne moraju biti povezane s poljoprivredom. Diversifikacija je, tvrdi Ramsey (2010), odgovor na razini pojedinog gospodarstva čije se posljedice vide na razini cijele lokalne zajednice pa i regionalno, a primarna strategija za postizanje diversificirane ruralne ekonomije je multifunkcionalnost poljoprivrednog gospodarstva.

Neka od gospodarstava koja smo istražili već su djelomično diversificirala svoju proizvodnju; naišli smo, tako, na maslinare koji proizvode ulje, na one koji kuhaju džemove i likere, na one koji nude smještaj turistima... Riječ je, međutim, tek o počecima, a ne o razvijenom stupnju diversifikacije. U ovom ćemo poglavlju naznačiti u kojem bi se smjeru, uzimajući u obzir perspektivu stanovnika, diversifikacija mogla razvijati. Iskustva poljoprivrednika diljem svijeta govore u prilog pristupu diversifikaciji utemeljenoj na mjestu. Diversifikacija, smatraju Halseth et al. (2010: 10), "nastaje kada se tradicionalne komparativne prednosti gospodarstava i lokalne zajednice iskoriste kako bi se stvorile mogućnosti razvoja proizvoda s dodanom vrijednošću”. Bitno je istaknuti i da razvijanje multifunkcionalnosti na razini OPG-a može pospješiti izglede za njegov opstanak, što pak može povećati mogućnosti za ekonomsku diversifikaciju u lokalnoj zajednici (Halseth et al. 2010). U Hrvatskoj najbolji primjeri 
diversifikacije, multifunkcionalnosti i održivog razvoja postoje u Istri, u kojoj se, u odnosu na (šire) dubrovačko područje, razvijaju u bitnome različite dinamike između turistički atraktivnih gradova na obali (Rovinj, Pula ... ) i, većim dijelom, ruralne, unutrašnjosti. O tome svjedoči i činjenica da je Istarska županija prva u Hrvatskoj izradila strategiju održivog razvoja, ali i istraživanja poput Vojnovićevog (2016) kojim je ustanovljeno da se unutrašnjost poluotoka odista i razvija održivo, odnosno "u suglasju s lokalnom zajednicom", i na način koji "ne ugrožava ostale gospodarske grane”, već se “dapače, potiče tradicijsku poljoprivredu i obrt” (Vojnović 2016: 183).

U kontekstu Dubrovnika, kao i u Istri, postoji mogućnost integriranja ponude urbanog i ruralnog aspekta, odnosno rasprostiranja turističke ponude na šire područje Grada (kod A1 Prostorno produbljivanje turističke ponude), što se nadaje kao logičan smjer razvoja turizma. Međutim, ta logika nailazi na prepreke, kao što je, doznajemo $\mathrm{u}$ intervjuima, trenutačna nesklonost turističkih agencija da dovode goste u dubrovačka sela (kod A6 Averzija grada spram rurala).

Oni idu u Konavle, idu u arboretum Trsteno, a ne dolaze ovdje i to je ono što nas ljuti... Gosti sa kruzera pođu u Neretvu i odrade vožnju lađa i imaju dole objed, a ne uspiju doć na Gromaču. (Gromača)

Miljoni turista dođu sa tim kruzerima i naprave kaos u gradu, nemaju jednostavno gdje, a ovdje mi ... sjedimo usred ljeta, nemamo što činit. Znači, mala gradska agencija koja bi koordinirala dolazak turista iz grada, da se grad rastereti, a da se ovdje ljudima ipak dovede... (Gromača)

Druga je prepreka, kako se doznaje iz intervjua, nesklonost mladih ljudi prema poljoprivredi, koja bi trebala biti dio turističke ponude. Mladi su manje skloni radu u poljoprivredi, radije se okreću turizmu i iznajmljivanju apartmana (kod A7 Averzija mladih spram poljoprivrede). U nekima od istraživanih naselja, ponajprije u Donjim selima i na Elafitima, turistička ponuda postoji, a sugovornici ističu potrebu za povezivanjem turizma i poljoprivrede.

Tko god ima turiste, malo i proizvodi. Dve, tri sobe i turisti koriste vaše proizvode. (Trsteno)

Izjave pojedinih sudionika istraživanja svjedoče o transformaciji svijesti o turističkim vrednotama i trendovima i govore o potrebi za drukčijim, novim pristupom turistu u kojem je ključna riječ “doživljaj”. U intervjuima se sugovornici, tako, referiraju na "autentičnost", doticaj s prirodom, lokalnom kulturom i ljudima (kod A2 Spoj poljoprivrede i turizma):

Ako pustiš gosta u vrt, to je drugo... Ako iznajmite sobu da oni gledaju u plafon - to je bezveze, to je prošlost. (Trsteno)

Stanovnici su svjesni brojnih neiskorištenih resursa koji bi se mogli upotrijebiti upravo za diversifikaciju djelatnosti i turističke ponude, posebno u Gornjim selima, 
gdje se OPG-ovi manje bave iznajmljivanjem apartmana. No tek neke od tih potencijala koriste.

Priče sa [salačkih] komina, već pet godina, svake godine je na kazalištu predstava kako se živilo prije, svake godine drugačije, eko sajam ide uz to. (Osojnik)

Imamo staru mlinicu, pokazivamo prezentaciju tradicionalnog načina obrade maslina, nama gosti zato dolaze. (Orašac)

Sočiva, domaći grahovi, suhi grah na juhu, zelena menestra u zimsko doba, to vam tri vrste kupusa i sušeno meso svinjsko, od ovce bravetina, mi to gostima [nudimo], to je specijalitet u zimskom periodu, oni to vole. (Gromača)

Sugovornici pokazuju da su svjesni širine i raznolikosti potencijala koje nalaze u lokalnoj zajednici, i u intervjuima rado predlažu turističke inovacije, od kojih neke slijede novije trendove u turizmu (kod A3 Turističke inovacije). Sljedeći odgovori otkrivaju aktivnog subjekta društvene mijene, koji je suprotstavljen stereotipno pasivnom, neukom seljaku u potrazi za savjetom konzultanta i organizacijom "odozgo". Moguće je da je blizina razvijene destinacije, koja prati turističke trendove, inspiracija za neke od citiranih prijedloga (kod A3 Turističke inovacije i kod A4 Socijalne inovacije).

Možda bi išli s ruralnim autokampom. Znači, partnerstvo sa susjedom. (Mrčevo)

Tu stvarno ima prekrasne prirode... ljepote u zaleđu ... Ima špilja ... Ja mislim da cijelo ovo selo treba pretvorit u jedan raspršeni hotel ili ovo eko selo, etno selo, kako već... Da svatko od nas bude tako mal, ali bude različit... Ali neko tu mora doć sa kapitalom i povezat nas i udružit... (Gromača)

Ima još stotinu ... ima svega ... Biciklističke staze napravit... Pješačke staze... Vidikovci, osmatračnice... Veliki potencijal - osposobiti Gromačku špilju, istraženu $1985 \ldots$... (Gromača)

Urediti lokvu! Presušila je jedino 1953. Ima neki natpis koji nije latinica ... po predanju je to grčka lokva. (Mrčevo)

Kušaonicu maslinovog ulja u maslinama [sam mislio] napravit... Pa fino u maslinama klupu za odmor, sjedanje, pa onda napisat latinski svaku vrstu masline, sve sorte, napravit staze kroz masline, čak za invalide... i kušaonicu od sortnih ulja maslina... i onda napraviti sve uz proizvode od maslina... (Gromača)

Prirodni i kulturni krajolik te kulturno i agrikulturno nasljeđe - uzgoj specifičnih biljnih sorti i njegovanje gastronomije, arheološka nalazišta i folklorna baština - posebnosti su dubrovačkih sela i značajan turistički potencijal. No, da bi se ostvario, potrebno je "diversificirati lokalne interese i u poljoprivrednom sektoru i kroz nove sek- 
tore poput turizma i agritainmenta"13 (Halseth et al. 2010: 12). K tome, zajednički, komplementaran nastup na turističkom tržištu preduvjet je kvalitetnog razvoja, dok razjedinjen pristup može dovesti do nelojalne konkurencije, što su neki od sugovornika i istaknuli kao problem (kod A9 Nedostatak lokalne suradnje i nesolidarnost).

Znate što smo mi doživjeli - ja nađem poso, dođu u mene, grupa gosta, sutra uveče čovjek vozi u susjeda... Jer meni susjed, pokvareno, pođe tamo i reče, e kolko ti je ona dala cijenu - 150, ma kakvi 150, dođi u mene, ja ću ti dati po 130. (Gromača)

Dubrovačkim selima ne nedostaje ideja i resursa, već organizacija i koordinacija ideja, ljudi i djelatnosti. Napokon, i empirijska istraživanja potvrđuju kako diversifikacija često izostaje zbog izostanka lokalnog vodstva (Argent, Walmsley i Sorensen 2010). U interpretaciji smo utvrdile snažan osjećaj nezadovoljstva radom više lokalnih institucija i nepovjerenje u lokalne političke strukture (kod A10 Nepovjerenje u institucije), što može biti razlog nedostatka inicijativa lokalnog stanovništva. Daljnja bi istraživanja mogla tražiti uzroke problema u lokalnoj zajednici upravo u toj vrsti razočaranosti.

Stanovnici, naime, očekuju da im lokalne institucije poput gradske uprave, razvojne agencije i drugih službi budu pomoć u organizaciji i koordinaciji (kod A8 Nedostatak institucionalne podrške). Uloga lokalne samouprave i popratnih institucija u ruralnom razvoju podrazumijeva, u puno većoj mjeri od postojeće, primjenu participativnih modela u razvijanju politika, u skladu s kojima institucije moderiraju i pružaju financijske modele, a lokalno stanovništvo, uključujući udruge i druge lokalne dionike, odlučuje što je primjereno razvoju njihove zajednice.

Jedno od istraživačkih pitanja odnosilo se na zainteresiranost sugovornika za edukaciju o EU fondovima i procjenu njihovog kapaciteta za prijavljivanje projekata. U intervjuima gotovo svi sugovornici izjavljuju da su za takvu edukaciju zainteresirani (kod A5 Interes za edukaciju), no smatraju da informacije o EU fondovima treba "približiti ljudima" jer su internetske stranice posvećene tim temama "prekomplicirane” i zainteresiranima umanjuju motivaciju. Također, navode kako su birokratski procesi koji se od njih očekuju prezahtjevni, dok je institucionalne, administrativne podrške premalo (kod A8 Nedostatak institucionalne podrške).

Edukacija o EU - to da, ljudi tu ništa ne znaju, ja prvi, na TV to toliko zakompliciraju za SSS, a kamoli nižu. (Zaton)

Edukacija i korištenje europskih fondova - pa bi pomoglo, samo treba administraciju ... smanjit, pojednostavit, ili neki ured otvorit da ja mogu gori tamo riješit jer ja imam ... dam ideju, da mi oni to rješavaju, jer nemam ja vremena ići po uredima tražit. (Gromača)

Volio bih neka dodatna sredstva, ali nemaš vremena za birokraciju. (Osojnik)

\footnotetext{
${ }^{13}$ Agritainment je spoj riječi agritourism i entertainment - agroturizam i razonoda.
} 
I u ovoj temi, kao i u drugima, naši se sugovornici kritički odnose spram nedostataka i poteškoća u korištenju fondova. Kritike koje navode odnose se na nespremnost institucija za adekvatnu edukaciju, nezainteresiranost mladih za poljoprivredu i nesređene vlasničke odnose. Uz to, kritiziraju i kriterije i procedure povezane s dodjeljivanjem potpora: plaćanje po hektaru umjesto po količini proizvedenog, nedostatak kontrole, izostanak kazni za okrutno ponašanje prema životinjama (kod A10 Nepovjerenje u institucije).

Idemo na sastanak u DUNEA-u [Regionalna razvojna agencija Dubrovačkoneretvanske županije], a ja nakon dva sata na kompjutoru znam više od njih. Needuciranost osoblja ... Izgubiš cijeli dan za nešto što za sat sam pročitaš. (Orašac)

Fondovi su dobrodošli, ali danas mladi ljudi nemaju radnih navika, kod nas se ne radi, ne pomažu tome fondovi. (Orašac)

Poticaj se dijeli nepošteno - gledajte koliko je to u nas luda država ... Imamo čovjeka jednoga, na tu kravu bušu što je zaštićena je bio poticaj veliki samo da bi ta autohtona vrsta opstala i ljudi su držali te krave... I on drži sto krava tih i država mu daje poticaje, ali niko se tu nije zapito šta si ti proizveo ove godine... Niko... On te krave drži gladne... On ih drži na konopu samo da su žive... (Gromača)

S druge strane, rijetki sugovornici koji imaju iskustva u prijavi na neku od mjera ruralnog razvoja hvale razvojne agencije koje su ih informirale i poticale u prijavi projekata.

Jedan od potencijalnih zamašnjaka lokalnog ruralnog razvoja, pogotovo u kontekstu EU fondova za ruralni razvoj, je i Lokalna akcijska grupa, koja, pod imenom LAG 5, djeluje na području južnog dijela Dubrovačko-neretvanske županije, ali zasad ne obuhvaća Konavle, Župu, te ruralna područja Grada (kod A9 Nedostatak lokalne suradnje i nesolidarnost). Tako je Grad Dubrovnik još uvijek prikraćen za prednosti ruralnog razvoja kakav zastupa LEADER, a koji je, u hrvatskoj izvedbi, odviše uvjetovan lokalnim političkim kontekstom (Lukić i Obad 2016).

\section{Zazivanje zadrugarstva i ostali nostalgični narativi}

Uvođenje višestranačja i kapitalizma u Hrvatskoj 1990-ih nije za posljedicu imalo i obnovu "izvornih zadružnih načela, autonomije i demokratskoga ustroja" (Pejnović, Radeljak Kaufman i Lukić 2016: 29). Štoviše, "zadrugarstvo je ostalo na margini političkih interesa i društvenih zbivanja” (ibid.), a pojedini autori smatraju kako stavove prema njemu i danas negativno određuje razdoblje prisilne kolektivizacije nakon Drugoga svjetskog rata (ibid.: 25).

Nagli porast broja zadruga bilježi se tek s promjenom zakonodavnoga okvira 2000-ih godina, u razdoblju u kojem potpore zadrugama daje nekoliko različitih ministarstava i u kojem su na snazi skromni kriteriji za njihovo osnivanje. Do 2011. broj 
zadruga povećao se na više od dvije tisuće, no mnoge su od njih postojale samo na papiru.

Takvom legislativom i instrumentima razvojne politike potaknut je prividan razvoj hrvatskoga zadrugarstva (porast broja zadruga s malim brojem članova), dok je s druge strane osnažen proces njegova unutrašnjega urušavanja (smanjenje broja članova i imovine pojedinih zadruga). (ibid.: 31 )

U usklađivanju s pravilima koja donosi novi zakon 2011. gotovo polovica zadruga prestala je postojati. Broj zadrugara je, primjerice, pao za 35 posto, ali se ukupan prihod zadruga smanjio tek za 13 posto, što govori o poslovanju "nestalih" zadruga (Pejnović, Radeljak Kaufman i Lukić 2016: 32). No, Pejnović, Radeljak Kaufman i Lukić (ibid.: 32-33) pesimistično zaključuju kako taj zakon kao i, primjerice, njegove izmjene i dopune iz 2013. nisu u bitnome utemeljili funkcioniranje hrvatskoga zadrugarstva na međunarodnim zadružnim načelima i europskim standardima.

Prema Godišnjem izvješću o stanju zadružnog poduzetništva za 2016. godinu Hrvatskog centra za zadružno poduzetništvo, koji je utemeljen posljednjim izmjenama zakona 2014., u Hrvatskoj djeluje nešto više od 1200 zadruga, od kojih njih petstotinjak pripada sektoru poljoprivrede i šumarstva. Trend pada prihoda (2012 - 2014.) se u 2015. stabilizirao, a u 2016. su prihodi blago porasli, no ukupni je broj zadruga te godine pao. Ukupan prihod zadruga iznosi samo 0,5 bruto domaćeg proizvoda Hrvatske (Hrvatski centar za zadružno poduzetništvo 2017).

U Dubrovačko-neretvanskoj županiji bilo je, prema istim podacima, prijavljeno 49 zadruga s oko 1900 zadrugara i 136 zaposlenika, a uvjerljivo najviše prihoda ostvareno je u sektoru poljoprivrede (i šumarstva), koji je vrlo važan na područjima poput doline Neretve i Pelješca te na pojedinim otocima.

Relativno najveći utjecaj zadrugarstva na socijalni razvoj u Dubrovačko-neretvanskoj županiji (5,5\% ukupno zaposlenih) prije svega je odraz razvijenosti komercijalnoga poljoprivrednog zadrugarstva u funkciji opskrbe turističkoga tržišta, odnosno gradskih aglomeracija u priobalju i unutrašnjosti Hrvatske. (Pejnović, Radeljak Kaufman i Lukić 2017: 68)

Pešorda i Gregov tvrde da su posljedice pridruživanja zadrugama "brži razvoj i povećana održivost ekonomije, jačanje zajednice, suradnja poljoprivrednika i malih poduzetnika koji djeluju zajedno, uče jedni od drugih i međusobno si pomažu” (2015: 2). Autorice navode i kako okupljanje inače raspršenih poljoprivrednih farmi u zadruge pridonosi "stabilnosti i poslovnoj suradnji [... ] u područjima u kojima su slabe”, priskrbljuje "više pregovaračke moći”, a zadružni mehanizmi djeluju i u pogledu "niskih prihoda, nedovoljno razvijenih tržišnih razmjena i ograničenih sustava društvene podrške" (ibid.: 14). Zadruge mogu "otvoriti vrata mnogim malim poduzetnicima da izađu na nova tržišta, prošire proizvodnju, poboljšaju profitabilnost i kvalitetu proizvoda”, one mogu osigurati nova radna mjesta, proširiti "prostor društvene suradnje" i dati "doprinos uravnoteženijem regionalnom razvoju Hrvatske” (Babić 
i Račić 2012: 308-309). Snažniji razvoj zadrugarstva mogao bi poboljšati "ukupnu gospodarsku efikasnost u Hrvatskoj" te pospješiti "kreiranje socijalno osjetljivijeg modela ukupnog ekonomskog razvoja" (ibid.).

Premda je više od polovice ispitanika u našoj studiji odgovorilo da je član neke udruge ili grupe, svega je osam ispitanika članova neke poljoprivredne, i to uglavnom maslinarske, udruge. Pritom čak 83 posto ispitanika odgovara kako je zainteresirano za udruživanje "u mjestu i okolici” (kod B1 Interes za lokalno udruživanje), a tek nešto više od 50 posto ih je zainteresirano za prekograničnu suradnju ( $\mathrm{s} \mathrm{BiH}$ ).

Kada je opća razina povjerenja u pitanju, čak 75 posto ispitanika odgovara kako “čovjek nikada ne može biti dovoljno oprezan”, a ostatak da se "ljudima može vjerovati” (kod B2 Opće nepovjerenje u ljude). Istodobno, više od 90 posto ispitanika smatra da je naselje u kojem živi raspoloženo više miroljubivo nego neprijateljski, te ih 96 posto odgovara kako bi od sumještana sigurno ili vjerojatno dobili pomoć. Nerazmjer između nepovjerenja u "apstraktne", neidentificirane ljude i prevladavajućeg povjerenja u sumještane možda treba tumačiti kroz sljedeći podatak. Naime, kada je riječ o povjerenju prema različitim skupinama ljudi, premoćna većina "potpuno" vjeruje samo pripadnicima obitelji. "Uglavnom” se vjeruje još sumještanima i kolegama na poslu, dok najveći broj odgovara kako službenicima u općini i Gradu “ne vjeruje previše”. Istraživanje, dakle, ponovno ukazuje na nepovjerenje u razne državne i lokalne institucije (kod A10 Nepovjerenje u institucije).

Odgovori koji se tiču udruživanja ukazuju na još uvijek prisutno očekivanje od države da planski pristupi zadrugarstvu kao društvenom projektu. Sugovornici smatraju da bi institucije zadužene za poljoprivredu trebale potaknuti udruživanje (kod B3 Očekivanje državne intervencije), dok se očekivani kapitalistički, poduzetnički subjekt koji bi inicirao rješenje postojećih problema nazire u pojedinačnim poduzetničkim proplamsajima, ali ne i, primjerice, u vidu socijalnog poduzetništva, koje je karakteristično za kasni kapitalizam.

Nema udruga, ni zadruga, potpuno neorganizirano društvo. (Orašac)

Problem je što nema niže razine od županije - to je jedina zadruga maslinara, to je previsoka razina, a prostor je rascjepkan. Treba napraviti udrugu maslinara dubrovačkog područja, pa Konavle... odmah bih se udružio. (Orašac)

U srazu s turizmom, kako je vidljivo iz iskaza snimljenog u primorskom Zatonu, poljoprivreda posustaje zajedno s potencijalom za zadrugarstvo (kod B4 Gašenje poljoprivrede).

Nema tu puno pravih poljoprivrednika, nema se tko udružit, ljudi se sad bave turizmom, voze turiste motornim čamcem. To je sad najveći hit, svi se bore da kupe brodove. (Zaton)

U intervjuima se također osjeća žal za razdobljima ("prije rata”) kada je zadruga u okolici bilo više, jer su one pogodovale postizanju bolje otkupne cijene (kod B6 Žal 
za predratnim zadrugama). Doba "prije demokracije”, međutim, ne naziva se jugoslavenskim ili socijalističkim, i tek takvo, pročišćeno od ideoloških i političkih konotacija, opstaje kao sjećanje na "bolja”, društveno uređenija vremena.

Sugovornici ističu i problem s veličinom i iscjepkanošću parcela (kod B7 Nedostupnost parcela).

Jedne godine [2000.] sam proizveo deset tona salate, sada to ne bih imao kome prodat. Nema zadruge, nema otkupa, nema ničeg. Pred rat je bilo 15, 16 zadruga, imali ste cijenu i viziju. (Orašac)

Bih [se udružio], ali ovo nije Slavonija, parcele su ispresijecane, pa ne znam što bih udružio. (Orašac)

Reakcije na prekograničnu suradnju su raznolike, ali većim dijelom u iskazima o mogućnosti udruživanja s poljoprivrednicima iz susjedne $\mathrm{BiH}$ nema entuzijazma. Općenito govoreći, na prekograničnu suradnju se ne gleda s naklonošću pa čak niti kao na realnu mogućnost (kod B8 Nesklonost prekograničnoj suradnji), premda ima sugovornika koji se rado prisjećaju nekadašnje, prijeratne suradnje. Iskazi nisu otvoreno neprijateljski, ali kroz elipse, ispuštanja ("nema smisla ...", "šsto mi imamo s njima ...”) možda progovara i nezavršeni proces rekoncilijacije.

Ja se ne bih udruživao... A kad bi došlo do udruživanja, radije bih udruživanje odi ... lokalno, a ne gori, što sad mi imamo s njima $[\mathrm{u} \mathrm{BiH}]$ ? (Orašac)

Osnovali smo udrugu maslinara, ali nije zaživjelo. Udružio bih se. A sa $\mathrm{BiH}$ - a nema smisla. (Zaton)

Ideja o lokalnom udruživanju prihvaćenija je od one o prekograničnom udruživanju, i sugovornici u tom kontekstu ističu pozitivne strane zadružnog načina poslovanja, kao što je dijeljenje sredstava za rad (kod B1 Interes za lokalno udruživanje). Tržišna logika kao da prevladava nad očekivano negativnim konotacijama socijalističkog nasljeđa, s kojim se zadrugarstvo još uvijek povezuje. Govoreći o prednostima povezivanja, više sugovornika upućuje na probleme s plasmanom svojih proizvoda, osobito onih koje proizvedu u većim količinama (kod B5 Nedostatak organiziranog tržišta).

Prije je bilo zadruga, nema sada. Dobro bi došle hladnjače pa da se bavimo limunom. (Zaton)

Najgore je što to što proizvedeš ne možeš prodat. To je problem. (Komolac)

Treba bit mlad da ti opremiš svoj proizvod, brzina i inventivnost ... ali starijim ljudima komotnije je da prodaju. Ja recimo kuham džemove, i ja sam dva, tri mjeseca u tome. Da ja to imam nekome odnijet da to zapakira, dizajnira... zadruga koja bi to preuzela bi to mogla. (Trsteno) 
Čini se da bi zadruga koja bi ujedinjavala poljoprivrednike ili čak i grupa poljoprivrednika koji su povezani samo neformalno najbolje poslovala kada bi se povezala $\mathrm{s}$ nekim vidom solidarne ekonomije $\mathrm{u}$ gradu, kakve su grupe solidarne razmjene i solidarne ekološke grupe diljem Hrvatske (Orlić 2014). To bi, međutim, zahtijevalo da proizvođači prijeđu u sustav ekološke proizvodnje.

Tržišnoj prepoznatljivosti lokalnih proizvoda pomoglo bi i osnivanje trgovine u samom Dubrovniku ${ }^{14}$ koja bi nudila poljoprivredne proizvode zadrugara, o čemu će više riječi biti u narednom poglavlju.

\section{Paradoks (polu)ekološke poljoprivrede - "Neću bit lud da sadim, a nemam kome prodat!"}

Jedan je od ciljeva ovog istraživanja bio utvrditi koji tip poljoprivredne proizvodnje prevladava u dubrovačkim ruralnim područjima, postoji li potencijal za razvoj ekološke proizvodnje i s kojim se preprekama u proizvodnji i distribuciji poljoprivrednici susreću.

Ekološka poljoprivreda u Hrvatskoj nedvojbeno je u porastu. Podaci za 2017. godinu pokazuju da je ekoloških gospodarstava bilo 4471 (od toga 3615 obiteljskih gospodarstava) koji su za ekološku proizvodnju koristili površinu od $112.829,1$ ha. ${ }^{15}$ Povećanje broja ekoloških gospodarstava od 2012. do 2017. iznosi 192 posto, a povećanje površina pod ekološkom proizvodnjom 253 posto. Iako ovi podaci navode na zaključak da je to poželjna i prosperitetna grana razvoja, ekološka poljoprivreda nailazi na brojne prepreke $u$ rastu i, još važnije, razvoju, koji podrazumijeva i pomake u kvaliteti, kao što je kontinuirana edukacija proizvođača i potrošača, širenje tržišta i institucionalna podrška. Unatoč tome što se tržište ekoloških proizvoda širi, potencijali tog tržišta još nisu u potpunosti ostvareni. Prema izvještaju IFOAM-a (International Federation of Organic Agriculture Movements) iz 2016., prepreke koje utječu na daljnji razvoj ekološke poljoprivrede u Europskoj uniji su: nejednak prioritet koji se u državama članicama pridaje ekološkoj poljoprivredi, ${ }^{16}$ nedjelotvornost opskrbnih lanaca ekoloških proizvoda, razvijanje proizvodnje primarnih sirovina dok je prerada manje razvijena i slabije regulirana nego u konvencionalnoj proizvodnji. Nedovoljna transparentnost tržišta, pak, za posljedicu ima nedovoljno informirane proizvođače, kupce i buduće ulagače (IFOAM 2016).

Ograničenja na koja najčešće nailaze ekološki poljoprivrednici u zemljama u razvoju, od kojih više njih nalazimo i u istraživanom području su: nedostatna tehnička znanja (zbog malog broja stručnjaka u tom području), nedostatak sredstava za ekološku proizvodnju (kompost, biopesticidi, biofertilizatori), manjkavost u području

\footnotetext{
${ }^{14}$ Ideju o trgovini u središtu Dubrovnika istraživačima su iznijeli djelatnici DURA-e prije provođenja istraživanja.

${ }^{15}$ Službeni podaci Agencije za plaćanja u poljoprivredi, ribarstvu i ruralnom razvoju (APPRRR) koje nam je Agencija ustupila 7. ožujka 2018.

${ }^{16}$ Primjerice, potpore koje se isplaćuju iz Programa ruralnog razvoja za zadržavanje i prelazak na ekološku proizvodnju u velikoj mjeri variraju - od 0,2 posto na Malti do 13,2 posto u Danskoj (IFOAM 2016).
} 
istraživanja i razvoja (o sortama i metodama uzgoja), metode prelaska na ekološku poljoprivredu koje smanjuju prinose, infrastrukturni nedostaci (transport i skladištenje), ograničena informiranost o tržištu i prodajnim kanalima, manjak radne snage i dr. (Twarog i Vossenaar 2003).

Zanimalo nas je teže li dubrovački poljoprivrednici ekološkoj poljoprivredi i s kojim se preprekama u proizvodnji, općenito, susreću. Premda nismo istraživali ekološke poljoprivrednike, neki se od navedenih problema odnose i na naše sugovornike, primjerice: nedostatak tehničkih znanja (kako proizvoditi ekološki) i nedovoljna informiranost o prodajnim kanalima.

U dubrovačkim selima nalazimo veći broj poljoprivrednika koji svoju poljoprivrednu proizvodnju nazivaju “djelomično ekološkom” jer koriste malu količinu pesticida i mineralnih gnojiva (kod C1 Poluekološki uzgoj).

Mineralna gnojiva koristim, ali vrlo malo, samo jednom polijem za oplodnju, dosta je to ekološki. (Orašac)

Gledamo što manje špricat. Prvo radi nas, a onda radi povjerenja kupaca. (Trsteno)

Neću certifikat, jer pošpricam dva puta godišnje. (Zaton)

Neće ekološka uspjet lako, prije je svaka kuća imala stoku... nema gnoja... nije eko ako ja kupujem hranu za stoku. (Šipan)

Navedeni citati ukazuju na sklonost poljoprivrednika da u manjoj mjeri koriste sredstva za zaštitu bilja (pesticide) i mineralno gnojivo. Naši sugovornici vlastitu proizvodnju smatraju "ekološkijom" od konvencionalne ("prskanje i po 15 ili 18 puta") i ponosni su na takav način gospodarenja. Pritom nijedan sugovornik ne navodi točne količine koje su dopuštene, odnosno na temelju kojih kriterija procjenjuje da je određena količina zaštitnih sredstava "minimalna" i "dovoljna”.

Jednu od prepreka prelasku na ekološku proizvodnju treba tražiti u začudnom, a ipak prevladavajućem stavu da je ekološka poljoprivreda - neostvariva (kod C2 Ekoskepticizam). Naime, mnogi poljoprivrednici s Elafita te iz Gornjih i Donjih sela smatraju da uroda ne bi bilo bez makar minimalne obrane od nametnika pesticidima, što posebno ističu za maslinu:

A ako se pojavi nekakva mušica jednom godišnje, ipak je treba polit, ako ga neš polit, nema maslina. (Mrčevo)

U literaturi se, nasuprot tome, navodi da je upravo maslina prilagodljiva načelima ekološke poljoprivrede (Godena 2011) pa ovakvi istraživački nalazi pokazuju da je edukacija o prelasku na ekološku proizvodnju prijeko potrebna (kod C3 Nedostatak znanja). Uostalom, na to ukazuje i zatečena razina poljoprivrednog obrazovanja, tj. izostanak formalnog poljoprivrednog obrazovanja i kontinuiranog, cjeloživotnog obrazovanja za poljoprivredu. Naime, od 53 sugovornika, svega njih dvoje ima formalno poljoprivredno obrazovanje (srednja škola). Neformalno obrazovanje ima 
dvije trećine sudionika - njih 36 - od kojih, međutim, tek četvrtina - njih osam ima položen neki od dobrovoljnih tečajeva. ${ }^{17}$ Nijedan, pak, tečaj koji je pohađalo tih osam sudionika nije iz područja održive ili ekološke poljoprivrede.

Sugovornici navode i problem koji proizlazi iz neobrazovanosti, a to je neispravno korištenje pesticida. Budući da su svi nositelji OPG-ova dužni položiti tečaj o upotrebi pesticida, čini se da oni ne jamče postizanje dovoljne razine stručnosti u tom području. U narednom citatu sugovornica prednost daje hrani koja nije "domaća” jer smatra da su u velikim sustavima standardi proizvodnje hrane viši.

Sad bi trebalo narod educirat, ja prva vidim da puno stvari ne znam. Uz tu prašinu - bordošku juhu, morao bi dati mjeru i upute, praktično, a ne 0,003 što piše na ambalaži, to ljudi ne razumiju. Stave otprilike, količinu koja nije adekvatna i onda koncentracija bude jača, prevelika. Recimo, kupovao se tuberajt prašivo, i izvadi netko svoj domaći krumpir, i sve zapraši protiv klijavosti, to je otrov. I sav sretan jede taj zaprašeni krumpir. Bolje onda kupit u Konzuma, jer je on stručno prašen. (Trsteno)

Uz manjak obrazovanja, problemi poljoprivrednika u Dubrovniku su i dostupnost parcela te pristup tržištu. Problem koji spominju gotovo svi sugovornici koji se bave poljoprivredom nedostupnost je udaljenih i raštrkanih poljoprivrednih parcela zbog zaraslosti putova koji do njih vode (kod B7 Nedostupnost parcela). U posljednja dva do tri desetljeća dio poljoprivrednog zemljišta nije obrađivan, a stoke je sve manje, pa i putovi koji vode do parcela nisu održavani. Posljedica je toga otežan ili posve onemogućen pristup. To je još veći problem uzme li se u obzir da mladi ljudi ne žele obrađivati zemlju kao i njihovi stari - "motikom kopati, a konjem nositi". Zato mnogi smatraju da bi čišćenje postojećih putova stvorilo uvjete da se mnoge sada nedostupne parcele stave u upotrebu, te da pojedini poljoprivrednici prošire proizvodnju. Većina ispitanika navodi dvojaku korist čišćenja tih putova - osim za pristup parcelama, oni bi ujedno služili i kao protupožarni putovi.

Tamo gdje ja imam zemlju ne možete traktorom, samo pješice, na leđima. Da imam pristup, svakako bi bila intenzivnija obrada. Imamo zemlju iza brda, ali dok dođeš tamo i nazad, ode dan. Nije dostupno. (Trsteno)

Opet podvlačim to, kad bi postojala volja da Grad, barem onu našu molbu koju mi iz Kotara upućivamo da je pročita pa da vidi... Bože, ajmo pomoć tim ljudima, kako napravit prilaznu cestu do njihovih maslinika. Jer imamo put do jednoga staroga sela ... To je selo sad pusto, prazno - Čajkovica. Stara Čajkovica... (Komolac)

Putevi prema neobrađenoj površini jer se ne obrađuje tamo gdje ne možete pristupiti. Najkvalitetnija zemlja se ne radi jer je u brdu. Ne obrađuje se 80 posto. (Osojnik)

\footnotetext{
${ }^{17}$ Ostalih 28 od 36 sudionika ima položen samo obavezni tečaj za uporabu pesticida.
} 
Treći se problem odnosi na tržišne uvjete u kojima dubrovački poljoprivrednici proizvode i prodaju svoje proizvode. I u prethodnim je istraživanjima potvrđen problem neorganiziranog ili nedovoljno razvijenog tržišta i plasmana robe za ekološke proizvođače (Pejnović, Ciganović i Valjak 2012; Renko i Bošnjak 2009). Taj problem (kod B5 Nedostatak organiziranog tržišta) dubrovačkih poljoprivrednika ima više aspekata, kao što su neprepoznatost posebnosti njihovih proizvoda izvan samih sela ili nemogućnost postizanja zadovoljavajuće cijene za ekološke proizvode, a bilo bi potrebno i proširiti krug potencijalnih kupaca (na, primjerice, turiste), te ponovno uvesti otkup lokalno proizvedene hrane od strane hotela i restorana kako bi se smanjila mogućnost "ucjene" i snižavanja cijena kod prekupaca.

U nekim se zemljama velik dio ekološke proizvodnje prodaje na konvencionalnim tržnicama i ona nije označena kao ekološka te time niti ne postiže više, "ekološke" cijene. ${ }^{18}$ Među sugovornicima u ovom istraživanju nijedan nema certificiranu ekološku proizvodnju, premda neki izjavljuju da povrće, voće i maslinovo ulje proizvode na ekološki način, bez ikakvih kemijskih sredstava. Međutim, lokalni kupci uglavnom ne cijene takve proizvode više, što potvrđuju i navodi naših sugovornika prema kojima se necertificirano ekološko maslinovo ulje, primjerice, prodaje po istoj cijeni kao i ono proizvedeno konvencionalno.

Nemate kome prodat ekološku ovdje, hotelu to ne možete prodat, oni u centrima uzimaju hranu, to je turizam. (Koločep)

Kad bi vi imali taj ekološki i proizvod... On ima svoju cijenu, vi ga nemate kome prodat... (Gromača)

Upravo je zbog lokalne neprepoznatosti dodane vrijednosti ekoloških proizvoda malo vjerojatno da će proizvođači u skorije vrijeme nastojati prijeći na certificiranu ekološku proizvodnju. Nedostatak educiranosti, uvjerenje poput onog da je maslinu ili grožđe ionako nemoguće proizvesti bez tretiranja kemijskim sredstvima dodatni je otežavajući faktor (kod C3 Nedostatak znanja).

U eko se ništa ne bi smjelo. A je li to moguće? Kako lozu bez prskanja? (Osojnik)

Ja ne vjerujem da se može nešto proizvest, a da se ne mora tretirat. Kako bi drukčije da nije sredstava? Ne znam kako bi se to moglo, možda ima, ali sumnjam da se može masovnije tako proizvodit. (Osojnik)

Jedan je od iznenađujućih nalaza istraživanja da neposredna blizina grada dubrovačkim poljoprivrednicima i njihovim proizvodima ne omogućuje pristup tržištu. Premda neki od njih prodaju voće na Tržnici Gruž, oni navode da su kupci, s izuzetkom starijih stanovnika koji, čini se, više cijene lokalno proizvedenu hranu, nedovoljno upućeni u važnosti i prednosti lokalne poljoprivredne proizvodnje pa, primjerice, od

\footnotetext{
${ }^{18}$ Primjerice, u Australiji 72 posto ekološke pšenice proda se kao ekološka, kao i polovica mlijeka, trećina govedine i samo 10 posto ovčetine i vune (Wynen 2003). U Češkoj se svega nekoliko ekološki proizvedenih proizvoda prodaje kao ekološki (Michelsen et al. 2000).
} 
preprodavača koji svoje proizvode lažno predstavljaju neretvanske mandarine kupuju kao dubrovačke. U nizu prevara i "ucjena" kojima su izvrgnuti, mnogi navode iskustva u prodaji voća prekupcima koji su im plaćali iznimno niske cijene (kod C4 Prevare i nelojalnost na tržištu). Više je intervjuiranih poljoprivrednika navelo kako su zbog takvih iskustava posjekli dugogodišnje nasade voća i drugih kultura (kivi, rogač, vinova loza ... ) ili, pak, urod uopće nisu obrali (kod B4 Gašenje poljoprivrede).

Prodali smo četristo kila kivija ... po dvije kune. Jel to sramota? Osamsto kuna... A mi potrošili dvije tisuće kuna vode... A u Zagrebu ih je prodavao po 15. Onda sam ih posjeko.; Ko limune prije dve godine... Tris i pe kuna u dućanu, a on nama plaća četiri kune... Nismo ubrali, nismo ništa, došla zima, zaledilo, propalo.; Najgore je što to što proizvedeš, a ne možeš prodat. To je problem. (Komolac)

Imali smo rogače pa smo ih posjekli, bila je cijena dvije kune po kilogramu. (Zaton)

Širenja poljoprivrede, bila ona ekološka ili konvencionalna, nema bez političke podrške koju zahtijevaju opsežnije akcije, kao što su uređenje putova do nedostupnih parcela, promoviranje lokalnih proizvoda te omogućavanje stvaranja lokalnih prodajnih kanala. Poljoprivrednici su izostanka takvog razvojnog pravca svjesni i, očekivano, prestaju proizvoditi hranu u većim količinama, za prodaju (kod B4 Gašenje poljoprivrede, kod C5 Nedostatak strategije).

Nema smisla sadit bez strategije... Apsolutno imam volju za to. Ali neću bit lud da sadim, a nemam kome prodat. (Orašac)

Dvije tone patata, nema se kome prodat, moj krumpirić pet kuna, a u marketu dvije kune. (Osojnik)

Prema navodima sugovornika, bilo bi idealno prodavati proizvode $\mathrm{u}$ samom gradu gdje bi, očekuju, imali bolji pristup kupcima zainteresiranima za ekološke ili "poluekološke" proizvode, bilo da je riječ o turistima u sezoni, ili o Dubrovčanima i Dubrovkinjama izvan sezone. Ispitanicima su u anketi ponuđeni prijedlozi za razvoj dubrovačkih sela i poljoprivrede, od kojih je među najprihvaćenijima bio prijedlog otvaranja trgovine unutar zidina u kojoj bi lokalni poljoprivrednici prodavali proizvode i postizali poštenu cijenu. Sudjelovanje u takvom prodajnom mjestu moglo bi se koordinirati putem poljoprivrednih zadruga, o čemu je više riječi bilo u prethodnom poglavlju.

Osim spomenutih, poljoprivrednici navode i probleme sa skupoćom vode, nesređene vlasničke odnose na poljoprivrednim parcelama, nedostatak inspekcijskih kontrola, veterinara i poljoprivrednih savjetodavaca za stočarstvo (većinom su orijentirani na maslinarstvo), nedostatak poljoprivredne infrastrukture (mljekomat, separator ulja, punionica meda, hladnjača, klaonica), nedostupnost stajskog gnojiva zbog manjka stoke u tom području te sve češća oboljenja biljaka. 
Naši su sugovornici motivirani za poljoprivredu, ali su svjesni i da pripadaju možda posljednjoj generaciji koja je na tom području vezana uz zemlju. U intervjuima naglašavaju potrebu za udruživanjem i organiziranjem tržišta primjerenog proizvodnji, no takve se promjene bez organizacijske i administrativne pomoći Grada neće dogoditi. Opstanak poljoprivrede na području Dubrovnika stoga nije izgledan. Starenje poljoprivrednika, orijentiranost mladih na iznajmljivanje apartmana, sječa dragocjenih nasada u znak otpora nepravednom tržištu... Sve to dovodi poljoprivredu u dubrovačkim ruralnim područjima u vrlo krhku i nesigurnu, neodrživu poziciju.

\section{Zaključak: non bene pro toto...}

Svaki od triju razvojnih smjerova kojima smo se posvetile $u$ analizi $u$ istraživanoj se ruralnoj zajednici suočava s preprekama. U slučaju ekološke proizvodnje, prepreka je manjak tržišta senzibiliziranog za vrijednost pribavljanja lokalnih proizvoda proizvedenih bez pesticida i umjetnih gnojiva. U slučaju diversifikacije, to je nedostatak političke inicijative da se turističke aktivnosti, na održiv način, prošire na ruralni teritorij Grada. Kada je riječ o ulasku u zadruge, prepreka je manjak povjerenja u ljude općenito, ali i u lokalne institucije te, istodobno, očekivanje od istih tih institucija da "poduzmu nešto".

Ako je blizina velike turističke destinacije i ublažila neke negativne nacionalne trendove, kao što su nezaposlenost ili radne migracije u inozemstvo, izostanak jasnih razvojnih perspektiva “odozgo" u lokalnom kontekstu u suodnosu je sa zanemarivanjem ruralnih područja na nacionalnom nivou. Upravo zato smatramo da bi razvoj dubrovačkog ruralnog područja trebao početi iznutra, snaženjem zadružnog djelovanja uz pomoć edukacije o prednostima zadružnog načina poslovanja. U zamišljenoj bi razvojnoj perspektivi trebalo slijediti teritorijalno širenje turističke ponude $u$ Gradu kroz jačanje zastupljenosti ruralnog turizma. I napokon - prelazak na ekološku poljoprivredu, koja bi lokalnim poljoprivrednim proizvodima, ponovno, bez velikih ulaganja, priskrbila dodanu vrijednost i izvan sezone. Naš je pristup ovom istraživanju i u teoriji i u praksi bio usklađen sa zahtjevima neoendogenog pristupa - i sama činjenica da je istraživanje rađeno za Razvojnu agenciju Grada Dubrovnika upućuje na to da određena razina participativnosti u planiranju lokalnih ruralnih politika već postoji. Prepreke poticanju takve vrste razvoja, međutim, i dalje su jake. Manjak povjerenja u institucije, čini se, priječi stvaranje inicijativa odozdo, dok odozgo izostaje interes za ruralne krajeve koji iziskuju ulaganja i razvojne vizije, bez kratkoročno "utrživih" rezultata.

Provedeno istraživanje pokazuje da je zatečeno stanje dubrovačkog rurala paradoksalno jer važni uvjeti za razvoj postoje. Riječ je o gradu koji ima sredstava za potrebna ulaganja i snažnu potrebu da se u sezoni urbana jezgra rastereti. Ali, na lokalnom nivou izostaje svijest o tome da održivi razvoj nije pomodarsko geslo. Stoga, umjesto zagovaranja najprikladnijeg modela multifunkcionalnosti i uključivanja di- 
onika, u postojećem kontekstu dubrovačkog razvoja radije upućujemo na razmišljanje o pustoši koja bi kroz dvadesetak godina mogla zahvatiti ruralna područja Grada.

Ako postoji analitička kategorija koja prožima analizu triju istraženih razvojnih perspektiva, to je dezorijentiranost, zbog koje građani iziskuju da se vlast, putem nadležnih institucija, očituje o razvojnom smjeru ruralnih krajeva. U nedostatku održivih i integriranih politika od naših se sugovornika, čini se, očekuje da se iz seljaka jednostavno prometnu u suverene, samodostatne kapitalističke subjekte. No, $\mathrm{u}$ intervjuima se takve "pretvorbene" tendencije naziru tek u dijelovima razgovora u kojima je riječ o turizmu. Bismo li se usudili pretočiti to u lokalne smjernice za endogeni razvoj, razvoj iznutra, odozdo prema gore? Jer, čini se da i sama blizina turističke destinacije djeluje kao katalizator ideja za razvoj koji pogoni profit pa su i "endogena” viđenja ruralnog razvoja sumnjivo usklađena s logikom kapitala, uključujući tu i projekcije iskorištavanja resursa koji (još uvijek) čine nešto, u kulturnom smislu, svojstveno prostoru. A to, kao što vidimo, može biti i sumnja u ljude, izbjegavanje povezivanja i suradnje, usvojena bespomoćnost...

Mimo sustavnih razvojnih politika, naši sugovornici zamišljaju: biciklističke staze, gradsku turističku agenciju posvećenu ruralnim krajevima, ruralne autokampove, difuzne hotele, etno sela, kušaonice maslinova ulja, obnovu prirodnih i kulturnih znamenitosti... Naši sugovornici, uglavnom, nisu davali iskaze koji bi svjedočili o svijesti da se kvaliteta života u ruralnim krajevima može poboljšati uz pomoć drukčijeg registra mjera, kao što je, primjerice, povećanje broja socijalnih radnika, postizanje višeg stupnja edukacije, pospješivanje zdravstvene skrbi ili osnivanje društvenih domova. Mogu li, u kontekstu hrvatske (post)tranzicije, takvo što i zamisliti?

Ako je suditi po perspektivi sudionika istraživanja, društva kojem bi se pojedinac obratio ionako nema. Postoji, međutim, država od koje se, uglavnom, moli i očekuje pomoć, a jedini kapitalizam u kojem ta država aktivno sudjeluje i s kojim naši sugovornici imaju doticaja ionako se odvija unutar turizma. Koncept neoendogenog razvoja nije inspiriran takvim razvojnim kontekstom i zagovarani se model $u$ istraživano područje ne može jednostavno preslikati. Pritom najviše, čini se, nedostaje mehanizama osvještavanja neodrživosti sadašnjeg razvojnog smjera, na oba kraja razvojne vertikale.

Prihvaćajući, napokon, ono što je, čini se, jasno građanima iz ruralnih dijelova Dubrovnika, ispostavljamo niz kratkoročnih ciljeva i projekata koji bi mogli pratiti ocrtani razvojni put, kao što je uključivanje u lokalni LAG 5, otvaranje trgovine u centru Dubrovnika u kojoj bi se prodavali isključivo lokalni poljoprivredni proizvodi te osnivanje grupa solidarne razmjene, odnosno solidarnih ekoloških grupa, putem kojih bi se Dubrovčani opskrbljivali hranom i izvan turističke sezone. Nekim budućim istraživačima ruralnog dijela Grada Dubrovnika ispostavljamo prijedlog da razvojne perspektive promisle i izvan dominantne društvene paradigme. 


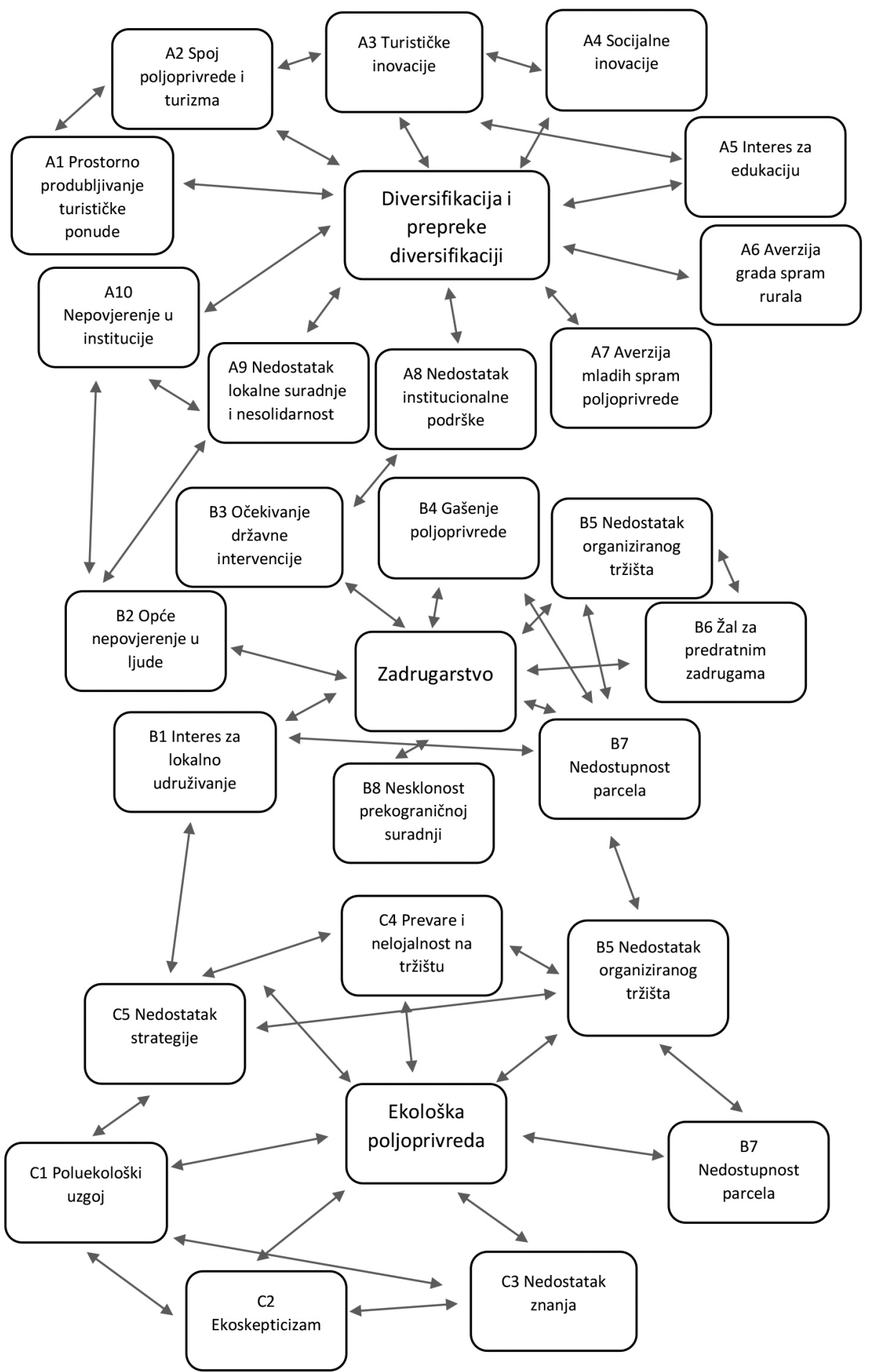

Prilog: Kodna shema triju kodnih grupa. Izradile autorice. 


\section{LITERATURA}

APPRRR. 2016. Upisnik poljoprivrednika. Broj PG-a 2016. [s. 1.]: Agencija za plaćanje u poljoprivredi, ribarstvu i ruralnom razvoju. https://www.apprrr.hr/upisnik-poljoprivrednika/ (pristup 16. 8. 2018.).

Argent, Neil, Jim Walmsley i Tony Sorensen. 2010. “Something Old, Something New, Something Borrowed, Something ... ? Rediscovering the Comparative Advantage of the 'New' Pastoral Economies of Northern New South Wales, Australia”. U The Next Rural Economies. Constructing Rural Place in Global Economies. Greg Halseth, Sean Markey i David Bruce, ur. Wallingford, Cambridge: CABI, 17-31.

ARKOD. 2017. Prikaz broja i površine ARKOD-a po naseljima $i$ vrsti uporabe poljoprivrednog zemljišta za 2017. godinu. Zagreb: Agencija za plaćanje u poljoprivredi, ribarstvu i ruralnom razvoju. https://www.apprrr.hr/arkod/ (pristup 21.8. 2018.)

Babić, Zdenko i Domagoj Račić. 2012. "Zadrugarstvo u Hrvatskoj. Trendovi, pokazatelji i perspektiva u europskom kontekstu”. Sociologija i prostor 49/3: 287-311.

Bagarić, Petar, Ozren Biti i Tea Škokić. 2017. Stranputice humanistike. Zagreb: Institut za etnologiju i folkloristiku.

Ban, Ivo i Vesna Vrtiprah. 2003. “Culture and Tourism in Dubrovnik”. Tourism and Hospitality Management 9/1: 1-16.

Bušljeta Tonković, Anita. 2015. "Sociološki aspekti mogućnosti održivog razvoja Središnje Like kroz prizmu ljudskog i socijalnog kapitala”. Sociologija i prostor 53/2: 163-180. https://doi.org/10.5673/sip.53.2.4

Dax, Thomas i Andrew Copus. 2016. "Research for Agri Committee. The Future of Rural Development Policy". U Research for Agri Committee - CAP Reform Post-2020 - Challenges in Agriculture. Workshop Documentation. Brussels: European Parliament, Directorate-General for Internal Policies, Policy Department B: Structural and Cohesion Policies, Agriculture and Rural Development, 221-301.

DZS - Državni zavod za statistiku. 2011. Popis stanovništva, kućanstava i stanova 2011. Prvi rezultati po naseljima. https://www.dzs.hr/Hrv_Eng/publication/2011/SI-1441.pdf (pristup 16. 8. 2018.).

DZS - Državni zavod za statistiku. 2017. Turizam u primorskim gradovima i općinama u 2017. https://www.dzs.hr/ Hrv_Eng/publication/2017/SI-1595.pdf (pristup 22.8.2018.).

DZS - Državni zavod za statistiku. 2018. Dolasci i noćenja turista u 2017. Priopćenje. https://www.dzs.hr/Hrv_Eng/ publication/2017/04-03-02_01_2017.htm (pristup 16.8.2018.).

Godena, Sara. 2011. “Ekološko maslinarstvo. Izazov 21. stoljeća”. Agronomski glasnik 73/3: 165-178.

Halseth, Greg, Sean Markey, Bill Reimer i Don Manson. 2010. “Introduction. The Next Rural Economies”. U The Next Rural Economies. Constructing Rural Place in Global Economies. Greg Halseth, Sean Markey i David Bruce, ur. Wallingford, Cambridge: CABI, 1-16.

Hrvatski centar za zadružno poduzetništvo. 2017. Godišnje izvješće o stanju zadružnog poduzetništva za 2016. godinu. http://zadruge.coop/upload_data/site_files/15685717151133565576743222798_godisnje-izvjesce-o-stanju-zadruznog-poduzetnistva-2016.pdf( (pristup 27. 8. 2018.).

IFOAM - International Federation of Organic Agriculture Movements. 2016. Organic in Europe. Prospects and Developments. Brussels: IFOAM EU Group.

Kunst, Ivo. 2017. "Image Redesign as a Tool for Safeguarding a Destination's Market Prosperity. The Case of Dubrovnik”. Sociologija i prostor 55/1: 55-75. https://doi.org/10.5673/sip.55.1.3

Lukić, Aleksandar i Orlanda Obad. 2016. "Novi akteri ruralnog razvoja. LEADER program i proces projektifikacije u ruralnim područjima Hrvatske”. Sociologija i prostor 54/1: 71-90. https://doi.org/10.5673/sip.54.1.4

Marsden, Terry i Roberta Sonnino. 2008. "Rural Development and the Regional State. Denying Multifunctional Agriculture in the UK”. Journal of Rural Studies 24/4: 422-431.

Michelsen, Johannes, Ulrich Hamm, Els Wynen i Eva Roth. 2000. The European Market for Organic Products. Growth and Development. Report Commissioned by the European Commission. Stuttgart: University of Hohenheim. https://www.uni-hohenheim.de/i410a/ofeurope/organicfarmingineurope-vol7.pdf (pristup 16. 8. 2018.).

Miljak, Toni, Lucija Bačić i Maja Kitić. 2012. "Ekoturizam kao poticaj razvoja poduzetništva u turizmu na primjeru Republike Hrvatske”. Učenje za poduzetništvo 2/2: 323-331.

Obad, Orlanda. 2012. "Prednosti podređenosti, slabosti emancipacije? Kako hrvatski poljoprivredni poduzetnici doživljavaju EU”. Studia ethnologica Croatica 24: 147-166.

Orlić, Olga. 2014. "Grupe solidarne razmjene. Počeci ekonomije solidarnosti u Hrvatskoj”. Etnološka tribina 37: 72-88. https://doi.org/10.15378/1848-9540.2014.37.02

Orlić, Olga, Petar Bagarić i Orlanda Obad. 2016. "Projektifikacija znanosti i ruralnih krajeva. Prilika za angažiranu etnologiju?”. U Srednjeevropsko povezovanje etnologov in kulturnih antropologov kot izziv današnjemu času / Srednjoeuropsko povezivanje etnologa i kulturnih antropologa kao izazov današnjemu vremenu. 13. Vzporednice med slovensko in hrvaško etnologijo / 13. Hrvatsko-slovenske etnološke paralele. Jadranka Grbić Jakopović, Tanja Kovačič, Anita Matkovič, Saša Renčelj Škedelj i Luka Šešo, ur. Ljubljana: Knjižnica Glasnika Slovenskog etnološkog društva, 68-86.

Pejnović, Dane, Anita Ciganović i Valentina Valjak. 2012. "Ekološka poljoprivreda Hrvatske. Problemi i mogućnosti razvoja”. Hrvatski geografski glasnik 74/1: 141-159. https://doi.org/10.21861/HGG.2012.74.01.08

Pejnović, Dane, Petra Radeljak Kaufman i Aleksandar Lukić. 2016. "Razvoj i suvremena obilježja poljoprivrednoga zadrugarstva na prostoru Hrvatske”. Hrvatski geografski glasnik 78/2: 5-48. https://doi.org/10.21861/ HGG.2016.78.02.01 
Pejnović, Dane, Petra Radeljak Kaufman i Aleksandar Lukić. 2017. "Utjecaj zadrugarstva na regionalni i ruralni razvoj Hrvatske”. Hrvatski geografski glasnik 79/2: 51-85. https://doi.org/10.21861/HGG.2017.79.02.03

Pešorda, Lucija i Zrinka Gregov. 2016. "Options to Boost the Development and the Sustainability of the Croatian Economy by Joining in Agricultural Cooperatives”. U Challenges of Europe. Growth, Competitiveness and Inequality. Eleventh International Conference Challenges of Europe. Proceedings. Split: Faculty of Economics, University of Split, 153-169.

Ramsey, Doug. 2010. "Rural Restructuring and the New Rural Economy. Examples from Germany and Canada". U The Next Rural Economies. Constructing Rural Place in Global Economies. Greg Halseth, Sean Markey i David Bruce, ur. Wallingford, Cambridge: CABI, 115-127.

Ray, Christopher. 2006. “Neo-endogenous Rural Development”. U Handbook of Rural Studies. Paul Cloke, Terry Marsden i Patrick Mooney, ur. London: SAGE, 278-291. https://doi.org/10.4135/9781848608016.n19

Renko, Sandra i Krešimir Bošnjak. 2009. "Aktualno stanje i perspektive budućeg razvoja tržišta ekološke hrane u Hrvatskoj”. Ekonomski pregled 60/7-8: 369-395.

Sayer, Andrew i Richard Walker. 1992. The New Social Economy. Oxford: Blackwell.

Shucksmith, Mark. 2010. "Disintegrated Rural Development? Neo-endogenous Rural Development, Planning and Place-Shaping in Diffused Power Contexts”. Sociologia Ruralis 50/1: 1-14. https://doi.org/10.1111/j.14679523.2009.00497.x

Svržnjak, Kristina, Mario Šarić, Sandra Kantar i Silvije Jerčinović. 2017. “Obilježja ponude ruralnog turizma dalmatinskih turističkih regija”. Agroeconomia Croatica 7/1: 117-125.

Šulc, Ivan. 2017. “Modificirani razvojni ciklus post-socijalističkih jadranskih otoka. Primjer otoka Mljeta”. Acta Turistica 29/1: 33-73. https://doi.org/10.22598/at/2017.29.1.33

Šulc, Ivan. [u tisku]. "Environmental Impacts of Tourism on the Eastern Adriatic Coast. The Case of South Dalmatia, Croatia”. U Atti del XXXII Congresso geografico italiano. L'apporto della geografia tra rivoluzioni e riforme. [s. n.], ur. Roma: Associazione dei geografi italiani.

Twarog, Sophia i René Vossenaar. 2003. "Obstacles Facing Developing Country Exports of Organic Products to Developed Country Markets”. U The Organic Guarantee System. The Need and Strategy for Harmonisation and Equivalence. Christina Westermayer i Bernward Geier, ur. Tholey: IFOAM, 122-128.

Vojnović, Nikola. 2016. Održivi turizam unutrašnje Istre. Pula: Sveučilište Jurja Dobrile u Puli.

Wynen, Els. 2003. "What are the Key Issues Faced by Organic Producers". U Organic Agriculture. Sustainability, Markets and Policies. OECD, ur. Wallingford: CABI Publishing, 207-220. https://doi. org/10.1079/9780851997407.0207

\section{Invisible Dubrovnik. A Study of Prospects for Development in a Local, Rural Community}

In this paper, the authors discuss possibilities for development in rural areas belonging to the City of Dubrovnik. The purpose of the paper is to determine the challenges farmers face in both their work and their everyday lives and the prospects for development in their local community. A field study was conducted in May 2016 through surveys and semistructured interviews of $\mathbf{5 3}$ farmers in villages and other settlements in rural areas belonging to Dubrovnik. The authors determined three complementary development objectives: diversification of rural activities, which is also connected to applications for EU funds; establishing cooperatives and developing cooperative-based means of collaboration; and transitioning to organic farming. In the analysis, the authors undertake a critical consideration of development obstacles to all three developmental aspects and suggest a means for potential for development to be used to benefit the local community. In accordance with neo-endogenous rural development, the authors conclude by presenting proposals for rural development that would go a long way towards a socio-economic integration of the City of Dubrovnik. The authors also emphasize obstacles within the local context that are standing in the way of this path towards development.

Keywords: rural development, diversification, cooperatives, organic agriculture, Dubrovnik 